Arch. Tierz., Dummerstorf 50 (2007) 1, 71-83

Department of Animal Science, Isfahan University of Technology, Isfahan, Iran

MOHAMMAD ALI NILFOROOSHAN and MOHAMMAD ALI EDRISS

\title{
Comparison of Holstein bull semen sources on milk traits in Isfahan province in Iran
}

\begin{abstract}
This research provides a comparison of productivity of daughters in Iran sired by bulls from Canada, Europe, Iran, and the United States. Data were collected by the Animal Breeding Center of Iran on pedigree and first lactation performances of 10,192 Holsteins sired by 186 imported (including: 39 European, 73 American, 74 Canadian) and 133 Iranian bulls, which had their first calving in 35 dairy herds in Isfahan province. The results showed that American and European daughters had the highest performances for milk yield. The highest mean for fat yield was related to European daughters. American sires on average had the highest genetic potential for yield traits; however, they had the lowest fat percentage among compared sire groups. Canadian sire group was intermediate relative to American, European and Iranian groups. Higher intercepts and regression coefficients of conversion equations for American sires showed that more returns will be achieved from one genetic point superiority of American sires relative to Canadian sires in the environments of Isfahan province. The Iranian sire group had the lowest predicted transmitting ability means for both milk and fat yields and a negative predicted transmitting ability mean for fat percentage. This study showed that due to low to intermediate predicted transmitting ability correlations between foreign evaluations and the evaluations made by this study, direct selection based on foreign national evaluations would not lead to optimal results for the traits concerned. So, the genetic potential/expression of imported genetic materials needs to be reevaluated by the Animal Breeding Centers of Iran.
\end{abstract}

Key Words: Holstein bulls, first lactation of daughters, milk traits, comparison of productivity, Iran

\section{Zusammenfassung}

Titel der Arbeit: Vergleich von Holstein Bullenherkünften in Bezug auf deren Töchtermilchleistungen in der iranischen Provinz Isfahan

Untersucht werden die Milchleistungen von Töchtern deren Väter aus Kanada, Europa, dem Iran und den USA stammen. Durch das iranische Zuchtzentrum wurden die Abstammungsdaten sowie die Erstlaktationsleistungen von 10192 Holstein Töchtern in 35 Milchrinderbetrieben, welche von 186 importierten (39 Europa, 73 USA, 74 Kanada) und 133 iranischen Bullen abstammten, untersucht. Die Töchter der amerikanischen und europäischen Bullen erreichten den höchsten Milch-, die europäischen den höchsten Fettertrag. Bei den verglichenen Bullengruppen zeigten amerikanische Bullentöchter das größte genetische Potential hinsichtlich der Milchmerkmale, jedoch das geringste beim prozentualen Fettgehalt. Die kanadische Bullengruppe lag zwischen den amerikanischen, europäischen und iranischen Herkünften. Die höheren Zuchtwerte und Regressionskoeffizienten bei Gleichungsumwandlungen zeigten, dass unter den Bedingungen der Isfahan Provinz auf Grund besserer Zuchtwerte,m die amerikanischen gegenüber den kanadischen Bullen einen besseren Ertrag erzielten. Die iranische Bullengruppe hatte die geringsten Vorhersagewerte sowohl bezüglich des Milch- und Fettertrages als auch des prozentualen Fettgehaltes. Die Studie zeigte, dass Leistungsvorhersagen, die auf ausländischen Schätzungen beruhen im Vergleich zu den in dieser Studie vorgenommenen, keine optimalen Ergebnisse einer Vorhersage bei den einzelnen Milchleistungsmerkmalen erwarten lassen. Es ist deshalb notwendig importiertes genetisches Potential durch das iranische Zuchtzentrum neu zu bewerten.

Schlüsselwörter: Holstein Bullen, 1. Laktation der Töchter, Milchleistungsmerkmale, Produktivitätsvergleich, Iran 


\section{Introduction}

The scope for genetic improvement is greatest through selection of males especially when artificial insemination is used. Therefore, unbiased evaluations of bulls to accelerate the genetic gains are essentials. According to POWELL et al. (1977) and VAN VLECK et al. (1987) in Holstein population, male selection has lead to a larger genetic gain than female selection.

There are growing markets for semen in developing countries. For a few decades in Iran, Holstein and Brown Swiss semen had been used for crossbreeding and grading up programs with native cattle. Holstein breed has been constituted by unremitting importation of animals and semen from Canada, USA, and some European countries especially Germany and the Netherlands.

Recently, due to extensive international trade in genetic materials, the number of countries in which a bull has relatives has increased (POWELL et al., 1997); but one of the problems is that, due to differences in the genetic base, scale, and units of measurement for each country, direct comparison of sire genetic value between countries is not possible (WEIGEL and REKAYA, 2000).

Tropical countries seeking more milk production have been encouraged to apply improvement programs based on changing over exotic genetic materials and posterior selection in the substituted gene pool (SMITH, 1988). This strategy is effective if production and marketing environments and selection objectives are similar. However, unfavorable interaction of genotype and environment $(\mathrm{G} \times \mathrm{E})$ would reduce potential benefits from a strategy based on the importation of genetic materials of superior potential (BANOS and SMITH, 1991). International dairy sire evaluations have traditionally been calculated using a two-step process; lactation records within each country are used to predict estimated breeding values, then these national breeding values are transformed to the genetic base, scale, and units of measurement of other countries by using conversion formulae or the multiple- trait across country evaluation method (SCHAEFFER, 1994). For many years regression based conversion equations have been used to convert estimated genetic merits in the exporting country to the equivalents in the importing country (WEIGEL and REKAYA, 2000; WEIGEL, 1997; POWELL, 1992, BANOS and SIGURDSSON, 1996). Genotype by environment interactions may cause different sire ranking in different environments. However, with using linear regression based conversion equations, sires do not rerank relative to their previous scale in the exporting country. Changes in the ranking of candidates across environments result in a genetic correlation of $<1$ between environments. In such a situation, genetic evaluation of sires in one environment may not be adequate predictors of progeny performance in another environment (WEIGEL et al., 1999). Current procedure for international bull comparisons used by INTERBULL center (Uppsala, Sweden), utilize results of national evaluations in various countries. Genetic evaluations computed by this system are expressed in the base and scale of each participating country. Consequently, for any country, foreign bulls can be directly compared with domestic bulls and simultaneous selection decisions within and across countries can be made (BANOS and SIGURDSSON, 1996).

HOLMANN et al., (1990) evaluated the profit of investing in US semen for use in three Latin American countries and concluded that these importations should be used strategically in environments with excellent feed and management, in order to obtain a positive response on the selection of imported genetic material. Also, economic returns 
from US AI germplasm were substantially lower in Colombia, Mexico, and Venezuela than in the US. However, opportunities for positive economic returns from investing in US semen were greater in Mexico than in Colombia and Venezuela. Milk yield expression of US Holstein genes is reported to be less in Mexican environments than US environments (CIENFUEGOS-RIVAS et al., 1999; POWELL and WIGGANS, 1991; STANTON et al., 1991).

The first objective of this study was to estimate genetic parameters, conversion equations, and a genetic comparison of Iranian and imported sire groups for milk yield, fat yield, and fat percentage at the climate of Isfahan province in Iran. The second objective was to compare phenotypic and genetic proficiencies of their daughters in Isfahan dairy herds.

\section{Materials and methods}

Isfahan climatology in brief: Isfahan province is located at latitude North $32^{\circ}$ and longitude East $51^{\circ}$, at an altitude of about $1600 \mathrm{~m}$ above sea level, which is classified as a subtropical climate. The annual mean precipitation is about $120 \mathrm{~mm}$, usually there is no rainfall during July, August, and September. The annual mean temperature at Isfahan is about $16^{\circ} \mathrm{C}$, and the mean temperature minima and maxima range from $-2^{\circ} \mathrm{C}$ (in January) to $+38^{\circ} \mathrm{C}$ (in July).

Data: Data were collected by the Animal Breeding Center of Iran in Isfahan province, on pedigree and performance information of Iranian Holsteins calved from 1994 to 2002 in 35 dairy herds. After excluding records of cows with unknown sire, and limiting age at first calving to 19 levels (from 21 to 39 months of age); a dataset consisted of pedigree information and first lactation records on milk yield, fat yield, and fat percent standardized to a $305 \mathrm{~d}$ and 2X-milking basis for 10,192 Holsteins. Sire origins of these cows were defined by the catalogue of pedigree production of Iranian and imported bulls from Animal Breeding Center of Iran (2003), and were classified into four groups (USA, Canada, Europe, Iran). Also, transmitting abilities of the imported bulls estimated in their home country were obtained, for milk yield, fat yield, and fat percentage traits. Based on the information of internal and imported semen usage (Animal Breeding Center of Iran, 2003), the frequency of sires used in Iran from each country can be shown as Figure 1.

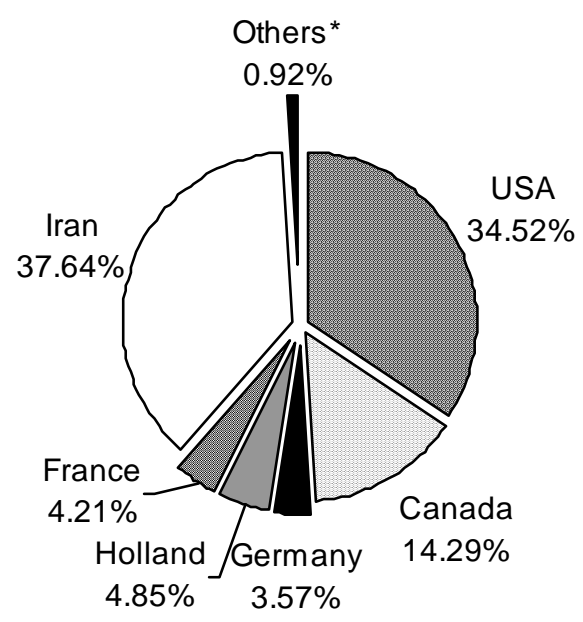

Fig. 1: Frequency of sires used in Iran (Anteil der aus den Herkunftsländern eingesetzten Bullen)

* Italy and Oceania 
According to this figure the most European semen exporting countries to Iran were: Netherlands, France, and Germany. Overall, European sires were less than $13 \%$ of sires used in Iran. Also, in this study European sires (including: Netherlands, France, and Germany) comprised $12.22 \%$ of all of the sires, which produced $6.15 \%$ of the progeny (Tabs. 1 and 2). Due to the low frequency of sires from these three countries and their daughters in the data set, their information was only considered in the genetic evaluations and in the comparison between daughters' performances and was not included in further comparisons. The structure of the data is presented in Table 1.

Statistical analysis: The following model was employed to obtain the variance components and the genetic parameters (heritabilities and predicted transmitting abilities) using derivative-free restricted maximum likelihood method applying the univariate procedure (DFUNI) of DFREML 3.0 $\beta$ package (MEYER, 1998), by the simplex way for each of the three traits concerned.

$\mathbf{Y}=\mathbf{X}_{\beta}+\mathbf{Z}_{\mathbf{a}}+\boldsymbol{\varepsilon}$

where: $\mathbf{Y}$ is the vector of observations, $\boldsymbol{\beta}$ is the vector of fixed contemporary groups, $\mathbf{a}$ is the vector of random direct additive genetic effects, and $\boldsymbol{\varepsilon}$ is the vector of random residual effects. $\mathbf{X}$ and $\mathbf{Z}$ are the incidence matrices relating records to fixed and direct additive genetic effects, respectively. The structure of the variances matrix of the model was as follows:

$\operatorname{Var}\left(\begin{array}{l}\mathbf{a} \\ \mathbf{e}\end{array}\right)=\left(\begin{array}{ll}\mathbf{A} \boldsymbol{\sigma}_{\mathbf{a}}^{2} & \boldsymbol{\emptyset} \\ \boldsymbol{\emptyset} & \mathbf{I} \boldsymbol{\sigma}_{\varepsilon}^{2}\end{array}\right)$

where: $\mathbf{A}$ and $\mathbf{I}$ are the numerator relationship matrix between animals, and the identity matrix with order the number of records, respectively. $\boldsymbol{\sigma}_{\mathbf{a}}{ }_{\mathbf{a}}$ and $\boldsymbol{\sigma}_{\boldsymbol{\varepsilon}}{ }_{\boldsymbol{\varepsilon}}$ are $\mathbf{V}[\mathbf{a}]$ and $\mathbf{V}[\boldsymbol{\varepsilon}]$, respectively. Contemporary groups (Herd-Year-Seasons of calving) were considered as fixed effect, and age at first calving, and direct additive genetic effects were considered as a covariable and random effect, respectively, in the model. Age at first calving has a significant effect on production traits (ATIL and KHATTAB, 2000; NILFOROOSHAN and EDRISS, 2004; TAWFIK et al., 2000) and positive associations has found between age at first calving and milk yield in both Egypt and Germany (TAWFIK et al., 2000). DFREML software enables the covariable to be linear, quadratic, cubic, or polynomial. In another study (NILFOROOSHAN and EDRISS, 2004) which examined the effect of age at first calving on milk traits, the trends of milk yield, fat yield, and fat percentage traits by age at first calving were curvilinear, so in this study, two regression coefficients were fitted for age at first calving (as a quadratic covariable).

$$
\left(\begin{array}{l}
y_{1} \\
\cdot \\
\cdot \\
y_{n}
\end{array}\right)=\left(\begin{array}{l}
\beta_{1} \\
\beta_{2}
\end{array}\right)\left(\begin{array}{ll}
\text { afc }_{1} & \text { afc }_{1}{ }_{1} \\
\cdot & \cdot \\
\cdot & \cdot \\
\cdot & \cdot \\
\text { afc }_{n} & \text { afc }_{n}{ }_{n}
\end{array}\right)+\left(\begin{array}{l}
\varepsilon_{1} \\
\cdot \\
\cdot \\
\cdot \\
\varepsilon_{n}
\end{array}\right)
$$


where: $\mathbf{y}$ is the record of the cow in the related trait, afc is the age at $1^{\text {st }}$ calving of the cow; $\boldsymbol{\beta}_{\mathbf{1}}$ and $\boldsymbol{\beta}_{\mathbf{2}}$ are the regression coefficients relating $\mathbf{y}$ to afc and $\mathbf{a f c}^{2}$, respectively; and $\boldsymbol{\varepsilon}$ is the random residual effect.

After estimating transmitting abilities for all animals in each trait, the predicted transmitting abilities (PTA) of bulls in each trait were considered to compare the efficiency of the sire groups for milk traits in the climate of Isfahan province, using Proc GLM of SAS software (SAS Inst., Inc., Cary, NC). Furthermore, daughters were classified into four groups based on their sire origin and daughters' performances of the sire groups were compared. Genetic trends of American, Canadian, and Iranian daughter groups in each trait were estimated by regressing daughters' PTAs on the year of birth.

Table 1

Summary of the data structure (Datenstruktur)

\begin{tabular}{ll}
\hline DATA & (NO). \\
\hline Animals in total & 12093 \\
Levels of fixed effect (HYS) & 495 \\
Levels of covariable (age at $1^{\text {st }}$ calving) & 19 \\
Base animals & 4987 \\
Animals with records & 10291 \\
Animals with unknown sire & 28 \\
Animals with unknown dam & 3561 \\
Sires with progeny records & 319 \\
American sires & 73 \\
Canadian sires & 74 \\
Iranian sires & 133 \\
European sires & 39 \\
Germany & 7 \\
France & 11 \\
Netherlands & 21 \\
Dams with progeny records & 4079 \\
Grand sires with progeny records & 201 \\
Grand dams with progeny records & 1239 \\
Mixed Model Equations (MME) & 12591 \\
\hline
\end{tabular}

In this study, the following conversion equation formula was applied to convert the home country PTAs of North American sires (USA and Canada) to the equivalent PTAs in Iran, especially in Isfahan province, using Proc REG of SAS software (SAS Inst., Inc., Cary, NC).

$\mathbf{P T A}_{\mathrm{ISF}}=\mathbf{a}+\mathbf{b}\left(\mathbf{P T A} \mathbf{E X P}_{\mathrm{E}}\right)$

where: PTA $\mathbf{A S F}_{\text {ISF }}$ and PTA $\mathbf{E X X}_{\mathbf{E P}}$ are PTAs in Isfahan province and the exporting country, respectively, $\mathbf{a}$ is an estimate of the genetic base difference between ISF $_{\text {and }}$ Exp and $\mathbf{b}$ is a slope representing the scale ratio.

\section{Descriptive parameters}

\section{Results and discussion}

The description of the population for all of the traits, and a performance comparison between daughters from different sire groups are shown in Table 2. Daughters sired by American and European sires were superior milk producers while Iranian daughters had the lowest yield. Also, European daughters had the highest fat yield performances. 
For fat percentage, the studied groups did not show a considerable difference (Tab. 2). POWELL and WIGGANS (1991) reported that daughters of US Holstein sires produced more milk in Mexican herds than did daughters of Canadian or Mexican sires. Higher performance of imported sire progeny in Isfahan dairy herds was reported by GHADERI (2002).

Table 2

Descriptive parameters for the data subsets on daughters of different sire groups for milk yield, fat yield, and fat percentage (Parameterbeschreibung der Töchterdatensätze unterschiedlicher Bullengruppen für Milch-, Fettgehalt und Fettprozent)

\begin{tabular}{lllll}
\hline TRAIT & DATA SUBSET & N & MEAN & SD \\
\hline Milk Yield (kg) & US & 2334 & 6457 & 1332 \\
& Canadian & 2052 & 6271 & 1357 \\
& European & 627 & 6450 & 1390 \\
& Iranian & 5179 & 6132 & 1308 \\
\hline Fat Yield (kg) & US & 2334 & 177.3 & 37.9 \\
& Canadian & 2008 & 175.0 & 40.7 \\
& European & 627 & 183.9 & 45.1 \\
\hline \%Fat & Iranian & 4929 & 171.4 & 36.4 \\
& US & 2334 & 2.80 & 0.45 \\
& Canadian & 2008 & 2.85 & 0.49 \\
& European & 627 & 2.90 & 0.52 \\
\hline
\end{tabular}

\section{Heritability and the variance components estimation}

Using Animal Model 1 of DFREML software, variance components (additive genetic, phenotypic, and residual variances) and heritabilities for milk yield, fat yield and fat percentage were estimated. The convergence criterion for stopping the procedure of the simplex algorithm of DFREML was chosen when the variance of $(-2 \log$ likelihood) in the simplex way was less than $10^{-8}$.

The heritability estimates and the variance components are presented in Table 3. Heritability estimates of milk and fat yields were $0.24 \pm 0.03$, and $0.27 \pm 0.03$, respectively, which are close to the other reports (ATIL and KHATTAB, 2000; TAWFIK et al., 2000; WEIGEL et al., 1999; GHADERI, 2002). Both milk yield and fat yield heritabilities were low to intermediate, which indicates that relying on more information on relatives is critical for planning selection and breeding strategies. Heritability of fat percentage was found to be $0.41 \pm 0.03$ in this study, which is close to GHADERI (2002) report. The higher heritability for fat percentage expresses the greater contribution of genetic effects in phenotypic variation. Thus, there would be a greater opportunity for genetic improvement in fat percentage. Hence, selection for fat percentage is expected to result in more responses than for traits with lower heritabilities, such as milk and fat yields.

Table 3

Variance components and heritability estimates for the studied traits (Varianzkomponenten und Heritabilitäten der untersuchten Merkmale)

\begin{tabular}{lllll}
\hline TRAIT & $\boldsymbol{\sigma}^{\mathbf{2}} \mathbf{a}$ & $\boldsymbol{\sigma}^{\mathbf{2}} \boldsymbol{\boldsymbol { \sigma } ^ { \mathbf { 2 } } \mathbf { p }}$ & $\mathbf{h}^{\mathbf{2}}$ \\
\hline Milk Yield (kg) & 350,372 & $1,082,438$ & $1,432,810$ & $0.24 \pm 0.03$ \\
Fat Yield (kg) & 261.63 & 697.96 & 959.59 & $0.27 \pm 0.03$ \\
\%Fat & 0.067 & 0.096 & 0.163 & $0.41 \pm 0.03$ \\
\hline
\end{tabular}




\section{Comparison between sire groups}

In this study, a comparison between Iranian, American, and Canadian sires was conducted. All the PTAs of each animal in each trait were evaluated by BLUP outputs via three single trait analyses, using Proc DFUNI of DFREML software (MEYER, 1998). Followed by dividing all the sires into four groups, sire groups were compared based on the PTA means for each trait. On average, imported (USA, Canada, and Europe) sires had $225.45 \mathrm{~kg}$ and $6.35 \mathrm{~kg}$ higher PTAs in milk and fat yields than Iranian sires $(P \leq 0.001)$. However, imported and Iranian sires did not differ significantly in \% fat PTA ( $0.004 \%$ more for the imported group). There were 319 sires including: 39 European, 73 American, 74 Canadian, and 133 Iranian sires involved in the genetic evaluations. However, due to the low number of sires from Germany ( $n=7)$, France $(n=11)$, and Netherlands $(n=21)$ and the low number of daughters per European sire, European sires were omitted from further genetic comparisons. Figure 2 presents the comparison between sire groups PTA means for milk yield, fat yield and fat percentage. According to this figure, American sires, on average, had the highest PTAs in yield traits; so, using American sires is recommended for genetic improvement in these traits. However, they had the least efficiency for fat percentage. This is partly due to the negative genetic correlation between milk yield and fat percentage which had been reported in other documents (VAN VLECK et al., 1987; GHADERI, 2002). Inconsideration of fat percentage genetic merit among US sires can increase the risk of reducing fat percentage performances, which is a challenge for most Isfahan dairy herds. Most Iranian dairy farmers are interested in increasing milk yield, and are usually faced with low fat percentage (especially in Isfahan province). Using sires with high genetic potential in both milk yield and fat percentage can go with their demands. In Mexico, the highest bull PTA for milk was achieved for bulls with both parents from the US, $469 \mathrm{~kg}$ higher than PTA for those with Canadian parents, and $491 \mathrm{~kg}$ higher than those with Mexican parents (POWELL and WIGGANS, 1991).

Canadian sires on average were in an intermediate level in all of the traits concerned, and their PTA means were closer to the population mean (zero). Although, on average, Canadian sires did not result in a fat percentage progress, they were helpful for genetic improvement in yield traits, but not as much as American sires. Because every genetic improvement program is conducted according to the home climate conditions, and there are considerable differences between the climates of Canada and Isfahan province, it seems that possible genotype by environmental interactions had a high influence on the genetic expression of Canadian sires. So, a study on $\mathrm{G} \times \mathrm{E}$ interactions between Iran and Canada is recommended. Also, different marketing conditions and consequently different emphases paid on each trait in selection indexes as well as genetic evaluation models utilized in each country may be important. Selecting progeny tested sires in another country with minor similarities in herd management may not lead to greater genetic progress due to differences between countries in climate or in genetic background of the cow population which may reduce the predictability of progeny performance (WEIGEL et al., 1999). In this study, the daughters of Iranian sires had the lowest yield and a negative genetic merit mean in fat percentage, too. Surprisingly, despite the negative genetic correlation between milk yield and fat percentage, Iranian sires had low efficiencies in both. As a result, inaccurate evaluations and selection programs for Iranian sires may reduce genetic 
progress in all of the traits concerned. Planning well-structured progeny testing, selection, and breeding programs is recommended for future Iranian bulls.

In the last two decades, the extensive use of Canadian and American semen has lead to higher frequency of North American Holstein genes in the Iranian Holstein populations. Most Iranian bulls were sired by Canadian or American sires, otherwise, lower genetic merit would have been observed for Iranian sires than present. Another consideration is that due to limited progeny testing programs in Iran, Iranian bulls usually are marketed without any progeny information and in some cases are selected solely on parent information, so their future daughter performance can be disappointing.

Besides genetic purposes, estimated genetic merits of animals can be used to evaluate genetic trends and structures in populations (SWALVE and HÖVER, 2003). In order to study the genetics of the sire groups, the genetic trend of daughters were evaluated through regressing daughter PTAs for each trait on the year of birth (Fig. 3). According to this figure, American and Canadian daughters had higher PTA levels for yield traits relative to Iranian daughters, which are supported by their higher performances and the higher PTA means of their sires relative to the Iranians. As a result of selection procedures on Iranian sires, mean PTA for milk yield of their daughters had an approximate $150 \mathrm{~kg}$ increase from year 91 to 99 while the fat traits (both yield and percentage) showed a gradual decline (Fig. 3). Also, American and Canadian daughters had a similar increase in milk yield PTA between 92 to 98 and 92 to 99, respectively. American daughters had a decrease in milk PTA trend from 98 to 99, which is coincident with a high increase in \%fat genetic trend. POWELL and WIGGANS (1991) reported that daughters of US sires born in 1985 in Mexico were $380 \mathrm{~kg}$ superior for breeding value for milk yield than daughters of Canadian sires and $336 \mathrm{~kg}$ superior than those of Mexican sires. Also, daughters' milk yield of North American sires in Mexico was higher than those of Mexican sires.

Between years 96 to 99, the genetic trends of American daughters had a good increase in fat yield and fat percentage. American sires had the lowest mean PTA for fat percentage among the studied groups (Fig. 2), but the situation in the US is likely to change due to increased emphasis being placed on components and reduced emphasis given to milk yield in recent years. SWALVE and HÖVER (2003) using data of cows born between 1992 to 1999 in four regions of Germany reported $111 \mathrm{~kg}$ and $3.2 \mathrm{~kg}$ average annual genetic trends for milk and fat yields, respectively, which seem to be much more than the present study. 

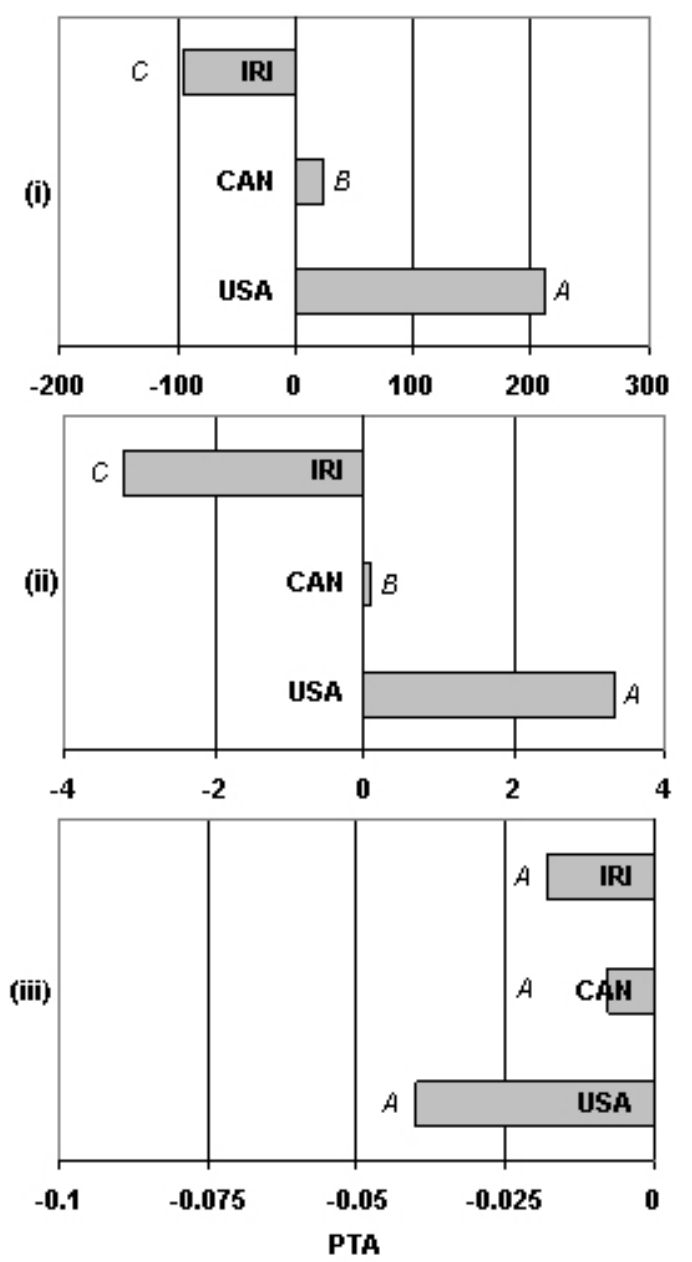

Fig. 2: Comparison between American, Canadian, and Iranian sires in kg milk yield PTA (i), kg fat yield PTA (ii), and fat percentage PTA (iii) (Vergleich zwischen einzelnen Bullengruppen bezüglich der Zuchtwertvorhersage für einzelne Merkmale)

Categories with different letters are significantly different $(P \leq 0.001)$
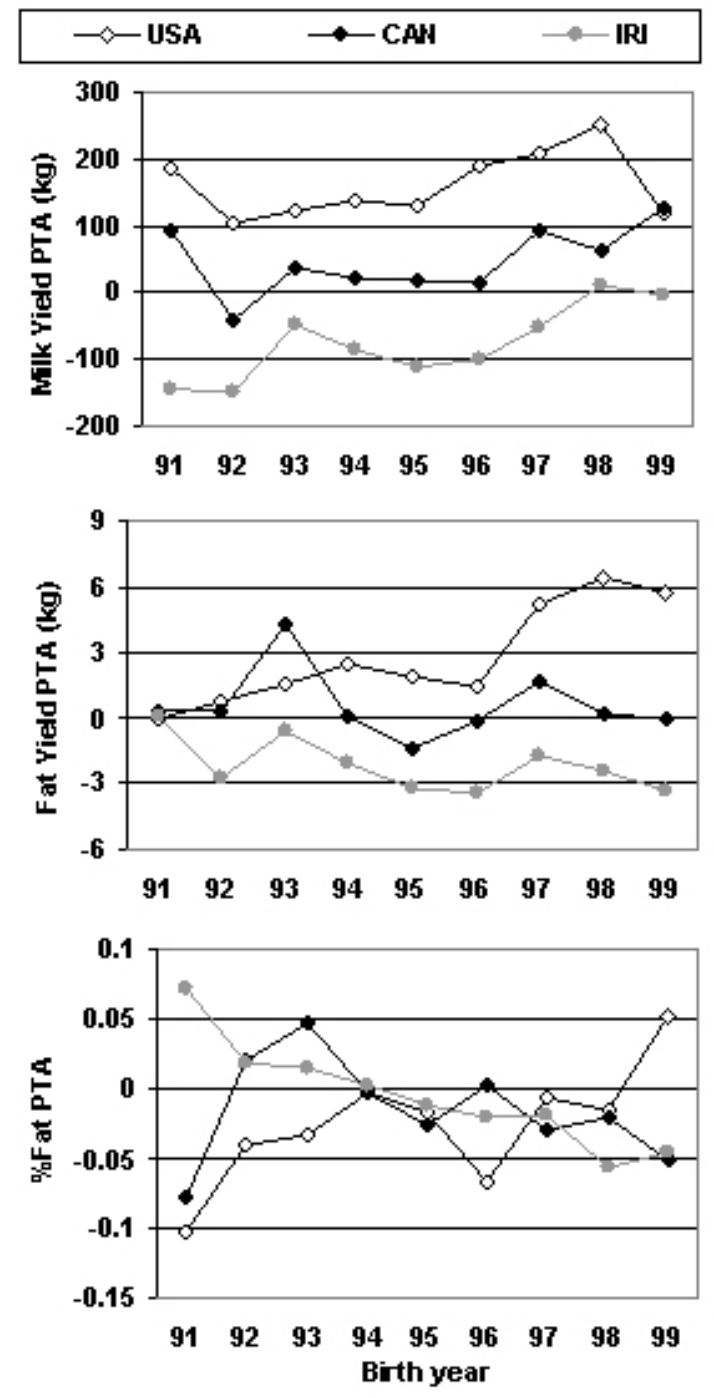

Fig. 3. Genetic trend of daughters of American, Canadian, and Iranian sire groups by the year of birth for milk yield, fat yield, and fat percentage (Genetischer Trend der Töchter unterschiedlicher Bullenväterherkünfte in den Untersuchungsjahren für die untersuchten Merkmale)

\section{Genetic variation within sire groups}

Table 4 presents the PTA standard deviations for each sire group in each trait. Iranian sires had the highest PTA variation in milk yield and fat percentage, and the lowest genetic variation in fat yield. According to their low genetic merit mean in all of the traits (Fig. 2), high genetic variation increases the probability of finding superior Iranian sires for the related traits to some extent, and low genetic variation could be a weak point for Iranian sires, because it reduces the probability of finding superior Iranian sires for the related trait (fat yield).

On average, American sires had the lowest genetic variation for milk yield; regarding their high genetic merit mean for milk yield (Fig. 2), this could be considered an advantage for American sires, because this low genetic variation can reduce the probability of finding inferior American sires for milk yield. 
Table 4

Standard deviations (SD) within different sire groups, and PTA correlations between genetic evaluations in this study and the evaluations in the exporting country (Standardabweichung zwischen den Bullengruppen und Beziehungen der Zuchtwerte, geschätzt in vorliegender Untersuchung und ausländischen Schätzungen)

\begin{tabular}{|c|c|c|c|c|c|c|}
\hline \multirow[t]{2}{*}{ COUNTRY } & \multicolumn{3}{|c|}{ PTA SD } & \multicolumn{3}{|c|}{ PTA CORR } \\
\hline & $\begin{array}{l}\text { Milk Yield } \\
\text { (kg) }\end{array}$ & $\begin{array}{l}\text { Fat Yield } \\
\text { (kg) }\end{array}$ & \%fat & $\begin{array}{l}\text { Milk Yield } \\
\text { (kg) }\end{array}$ & $\begin{array}{l}\text { Fat Yield } \\
\text { (kg) }\end{array}$ & \%fat \\
\hline USA & 316.4 & 10.15 & 0.16 & 0.45 & 0.38 & 0.50 \\
\hline Canada & 319.0 & 10.30 & 0.15 & 0.37 & 0.35 & 0.51 \\
\hline Iran & 351.8 & 8.04 & 0.20 & - & - & - \\
\hline
\end{tabular}

Estimation of correlations and conversion equations for North American sires

Table 4 represents the estimated correlation coefficients between PTAs in the home country and in Isfahan province. PTA correlations were low to intermediate for both American and Canadian sires, which shows that direct selection based on foreign PTAs would not be a good option in Iran (like else where), especially in Isfahan province, and the need for official conversion equations or international evaluations (a better choice) is very sensible. Also, estimating sire ranking correlations and $\mathrm{G} \times \mathrm{E}$ interactions between most important semen exporting countries and Iran would be helpful.

Intercepts and regression coefficients were estimated for conversion equations to convert PTAs on foreign bulls (USA and Canada) to PTA for Isfahan province in Iran (Fig. 4). Many factors affect size of intercepts including mean of true genetic differences between populations, and relative currentness of base definitions, also, factors affecting size of regression coefficients are physical measures (e.g., pounds vs. kilograms) and genetic measures (e.g., breeding value vs. transmitting ability) (POWELL et al., 1994).

Higher intercepts and regression coefficients for American sires (Fig. 4) showed that more returns will be obtained from one unit superiority (e.g. PTA or EBV) of American sires based on home country evaluations than Canadian sires in the environments of Isfahan province. Regression coefficients $<1$ show that for both American and Canadian sires lower returns will be achieve than in their home country. Conversion equations require evaluation on the scales of both countries for a number of bulls and permit estimates of genetic merit from one country to be expressed on the genetic scale of another country (POWELL and NORMAN, 1998). The three major concerns regarding the accuracy of conversion equations have been 1) preferential mating of foreign bulls, 2) preferential treatment of resulting daughters, and 3) appropriateness of the sample. Adoption of animal model procedures has largely eliminated the problem of preferential mating (POWELL et al., 1994). Linear based conversion equations place evaluations for bulls from a number of countries on the same scale (POWELL et al., 1994). Thus, bulls with converted evaluations do not rerank on a new scale. The system of across-country evaluation (SCHAEFFER, 1994) used by the INTERBULL center (Uppsala, Sweden) considers all data simultaneously; therefore, merits of individual bulls should be more accurate (POWELL and NORMAN, 1998). INTERBULL center uses national evaluation data from all participating countries to provide international proofs of dairy sires expressed on each country's genetic base and scale. INTERBULL considers the genetic correlations between countries less than one; therefore, each country has its own ranking and one international list is produced for each country. This helps semen importing countries 
make better decisions and receive higher returns from their investment. Furthermore, semen exporting countries could know how their own genetics could compete best in different countries. The acceptance of MACE evaluations employed by INTERBULL (SCHAEFFER, 1994) will give a greater accuracy for predicting Iran PTA from foreign information. As INTERBULL procedures continue to improve, conversions will become less useful because they only consider the data from two countries (POWELL et al., 1997).
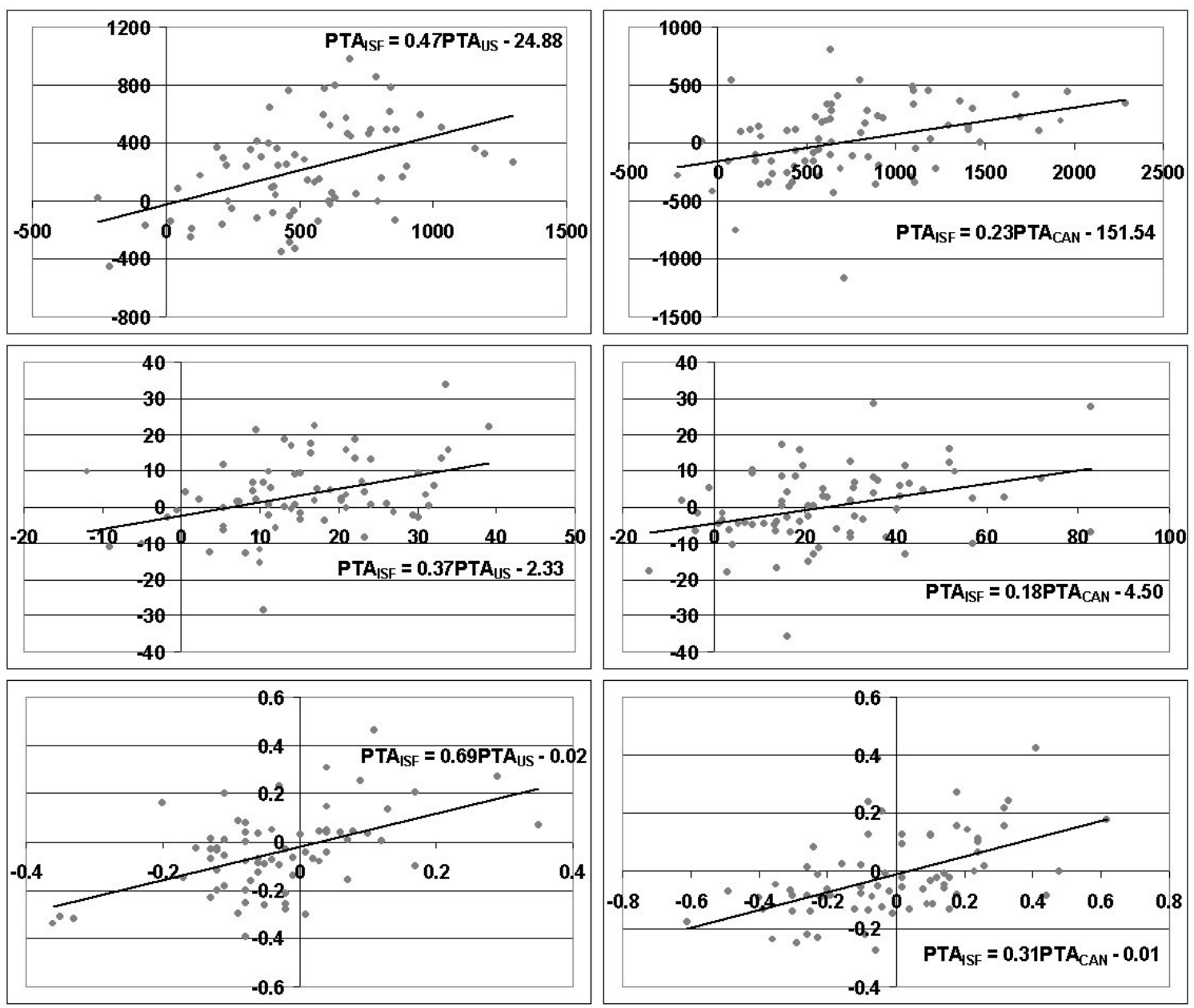

Fig. 4: Conversion equations of genetic merit for milk yield [ 2 plots at the $1^{\text {st }}$ line], fat yield [2 plots at the $2^{\text {nd }}$

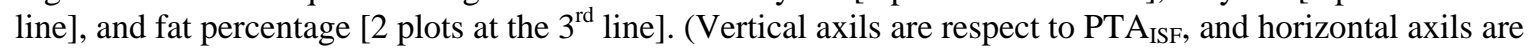
respect to PTA in the exporting country) (Beziehungen zwischen Zuchtwerten im In- bzw. Ausland geschätzt (von oben: Milch-, Fettertrag und Fettprozent, Ordinate Inlandschätzung, Abszisse ausländische Schätzung))

Due to differences in the genetic base and scale between countries, and genotype by environmental interactions which cause different genetic expressions between environments, direct comparison of animals between countries is not appropriate. The use of foreign semen has produced favorable results in Iran by supplying improved genetics to the Iranian dairy populations; however, using superior genetic materials more suited to the environmental conditions and management systems of the importer country should be considered to achieve optimum benefits.

Unfortunately, because of the low frequency of European sires and the low number of daughters per European sire, they were not considered in the sire origin comparisons, however, European sire group had the highest (statistically unreliable) PTA mean in all of the studied traits, which is not mentioned in the results. Also, their daughters had 
high performances in all of the traits concerned (Tab. 2). So, it would be worthwhile to increase semen importation from Europe (especially; Germany, France, and Netherlands. In recent years, semen importation from Germany has increased) in order to increase the frequency of European genes and to study this group with more data to provide reliable results for European sires. Although, production traits are the most important traits in Iran, there is a global interest on health and fertility traits. Therefore, the authors suggest further investigations to be done on health, fertility, longevity and etc.

\section{Acknowledgments}

Thanks to Mr. Esmaili at the registration \& recording office of the Animal Breeding Center of the Ministry of Agriculture in Isfahan province.

\section{References}

ANIMAL BREEDING CENTER of IRAN:

Pedigree Production of Iranian \& Imported Bulls. Catalogue No: 2 (2003)

ATIL, H.; KHATTAB, A.S.:

A comparison of different methods of estimating sire transmitting ability of some milk traits in a herd of Holstein Friesian cattle. Arch. Tierz., Dummerstorf 43 (2000), 115-122

BANOS, G.; SIGURDSSON, A.:

Application of contemporary methods for the use of international data in national genetic evaluations. J. Dairy Sci. 79 (1996), 1117-1125

BANOS, G.; SMITH, C.:

Selecting bulls across countries to maximize genetic improvement in dairy cattle. J. Anim. Breed. Genet. 108 (1991), 174-181

CIENFUEGOS-RIVAS, E. G.; OLTENACU, P. A.; BLAKE, R. W.; SCHWAGER, S. J.; CASTILLO-JUAREZ, H.; RUIZ, F. J.:

Interaction between milk yield of Holstein cows in Mexico and United States. J. Dairy Sci. 82 (1999), 2281-2223

GHADERI, M.:

Effects of Genetic and Non-genetic Variances on Milk and Some Reproductive Traits of Holstein Dairy Cattle of Isfahan Province (Farsi language). MSc thesis. Isfahan University of Technology, Isfahan, Iran (2002)

HOLMANN, F.; BLAKE, R. W.; MILLIGAN, R. A.; BARKER, R.; OLTENACU, P. A.; HAHN, M. V.:

Economic returns from United States artificial insemination sires in Holstein herds in Colombia, MEYER, K.: Mexico, and Venezuela. J. Dairy Sci. 73 (1990), 2179-2189

DFREML: Programs to estimate variance components by restricted maximum likelihood using a derivative-free algorithm. User notes, Version 3.0ß. University of New England, Armidale, Australia (1998)

NILFOROOSHAN, M. A.; EDRISS, M. A.:

Effect of age at first calving on some productive and longevity traits in Iranian Holsteins of the Isfahan province. J. Dairy Sci. 87 (2004), 2130-2135

POWELL, R. L.:

Direct and indirect conversion of bull evaluations for yield traits between countries. J. Dairy Sci. 75 (1992), 1138-1146

POWELL, R. L.; WIGGANS, G. R.:

Animal Model evaluations for Mexican Holsteins. J. Dairy Sci. 74 (1991), 1420-1427

POWELL, R. L.; WIGGANS, G. R.; SIEBER, M.:

Consistency of international genetic evaluations of Holstein bulls. J. Dairy Sci. 80 (1997), 2177-2183

POWELL, R. L.; WIGGANS, G. R.; VANRADEN, P. M.:

Factors affecting calculation and use of conversion equations for genetic merit of dairy bulls. J. Dairy Sci. 77 (1994), 2679-2686

POWELL, R. L.; NORMAN, H. D.:

Use of multinational data to improve national evaluations of Holstein bulls. J. Dairy Sci. 81 (1998), 2257-2263 
POWELL, R. L.; NORMAN, H. D.; DICKINSON, F.D.: SAS, 1997:

Trends in breeding value and production. J. Dairy Sci. 60 (1977), 1316

SCHAEFFER, L. R.:

SMITH, C.:

Multiple-country comparison of dairy sires. J. Dairy Sci. 77 (1994), 2671-2178

Genetic improvement of livestock using nucleus breeding units. World Anim. Rev. 65 (1988), 2-10

STANTON, T. L.; BLAKE, R. W.; QUAAS, R. L.; VAN VLECK, L. D.:

Response to selection of United States Holstein sires in Latin America. J. Dairy Sci. 74 (1991), 651664

SWALVE, H. H.; HÖVER, K.:

Examinations using the results of breeding value estimation for Holstein sires and cows in Germany (German language). Arch. Tierz., Dummerstorf 46 (2003), 113-126

TAWFIK, E.S.; MOHSEN, M.K.; SALEM, A.Y.; EL-AWADY, H.G.:

Study on Friesian herds raised in Egypt and Germany. I. Estimate of non-genetic effects and genetic parameters. Arch. Tierz., Dummerstorf 43 (2000), 101-114

VAN VLECK, L. D.; POLLAK, E. J.; OLTENCU, E. A. B.:

Genetics for the Animal Sciences. W. H. Freeman \& Co., New York, NY (1987)

WEIGEL, K. A.:

Accuracy of international conversions of elite sires and cows when conversion equations are based on linear regression. J. Dairy Sci. 80 (1997), 3420-3424

WEIGEL, K. A.; REKAYA, R.:

A multiple-trait herd cluster model for international dairy sire evaluation. J. Dairy Sci. 83 (2000), 815821

WEIGEL, K. A.; KRIEGL, T.; POHLMAN, A. L.:

Genetic analysis of dairy cattle production traits in a management intensive rotational grazing environment. J. Dairy Sci. 82 (1999), 191-195

Received: 2006-04-03

Accepted: 2006-11-28

Corresponding Author

Prof. MOHAMMAD ALI EDRISS

Department of Animal Science, Isfahan University of Technology,

ISFAHAN, IRAN. 86154

E-Mail: edriss@cc.iut.ac.ir 